\title{
On Translating Dalit Texts with Special Reference to Bali Adugal (Scapegoats)
}

\section{S. ARMSTRONG}

\begin{abstract}
The paper is a study in the politics of translation with reference to the Tamil Dalit play Bali Adugal. The play is structured around an inscription on human sacrifice and threaded with a conversation between.B.R.Ambedkar and Mulk Raj Anand, which has been extracted from Ambedkar's book The Annihilation of Caste. The paper contains three sections. The introduction discusses the relevance and importance of translating Dalit texts into English and other foreign languages. The important Dalit translations available in India and abroad have also been discussed in this part. The second part of the paper deals with the personal experiences of the writer of this paper in translating the Tamil Dalit play Bali Adugal into English supported by relevant theories of translation and culture referring to the practice of human sacrifice as narrated by James Frazer in The Golden Bough (Frazer 1993-94). The concluding section discusses the challenges that the translators of Dalit texts find themselves face to face with in the process of translation.
\end{abstract}


I say to the untouchable: Be a lion! Hindus sacrificed goats to the goddess Kali for power. You be your own light - atta dipa bhav!

-Dr. B. R. Ambedkar (Ambedkar 1980:130-35)

The translation of Dalit literatures in India into English and other foreign languages like French and Spanish is a leapfrogging transformation for providing a space for sharing the Indian dalit's age-old stigma of untouchability with foreign readers. The Indian Dalit literatures not only discuss social discriminations now, they also assert their identities and prove their creative potentialities. In this process, the translation of Indian Dalit texts plays a vital role in creating historical awareness as well as historical sense through this interlinguistic process. The inference of historical sense will help the historical recovery of the dalits through the mode of translation. These translations will create a socio-cultural space for intercultural dialogues among other people and the Othered or Unempowered or Disoriented peoples in this world. In this historical journey, translation becomes an act of socio-cultural practice, which is an alternative sphere for translation rather than a mere change of linguistic form. Recent translators concentrate more on the transformation of cultural milieus than of mere verbal transformative process into an alien tongue. They also play a crucial role in liberating the dalits in a social system as one can see in India.

This article is an attempt to highlight the problems involved in translating Dalit texts into English with special reference to Bali Adugal, a Tamil Dalit play, written by K.A.Gunasekaran. The article tries to show that the play itself is a site of multiple layers of translated texts within texts and dialogues within dialogues as the play is built around a fragment of an inscription and threaded with a conversation between Ambedkar the redoubtable Indian figure and Mulk Raj Anand, the renowned Indian English author. The final part of the essay seeks to construct a new theory of translation by taking a cue from one of the characters in the play, who is a eunuch. 
The translator who is the second writer of the intended translated text plays a more responsible role than that of the original writer. The translator who willingly or unwillingly takes up the translation of a Dalit text tends to become a cultural ambassador and he has to bear in mind the social commitment of rendering a literature of a people who have been excluded in all realms of society even before their birth. In this context, translations of Dalit texts assume a pivotal role in the process of transformation of the mindsets of people living in a country, which practices caste-based discrimination that denies even a dignified existence of millions of Dalits.

In the kind of freedom a translator takes, there are chances of 'aberration' and 'misrepresentation' of the source text. Dalit literature deals with socio-cultural liberation and a translator needs to be aware of this. Translation is no longer a mere change of a linguistic container. The role of translation and that of the translator has now changed. He has become a cultural mediator, who traverses the resonance zone between cultures.

Dalit literatures are no longer emotive expressions of pain and suffering. Being liberative in nature, they talk about the Dalit lifestyle, ceremonies, rituals and rites that form the background of their expressions. They are also intertwined with their real life experiences. These literatures have to survive against distortion and misrepresentation by market forces, both by the mediators within and outside India. Translators who delve deep into these literatures need to be careful in transforming Dalit's socio-cultural practices. In adapting Western theories in translation and literature, the translator and the writer have to conceptualise the Indian Dalit situation in their minds. A translator who is associated with Dalit literature seems to be in a much better position and can bring better impact in translating the source text if he/she has: 
- Personal association with the author, the people and the native speakers of the source language and can avoid problems in the acquisition of dialects and of Dalit slang

- Familiarity with the marginaled submerged experience to translate the milieus Emotional affinity/sensibility towards the social problems of Dalits.

- An activist's impulse to contribute to the struggle for liberation.

- Active participation in creating capacity-building or affirmative actions to help the mainstreaming and the social habilitation of Dalits.

These suggestions might help the translator in the process of illumination and representation in a worthwhile and desirable manner and are likely to impact the target text.

\section{Translations of Tamil Dalit Texts into English}

Earlier, Dalit literatures often dealt with suffering and pain. Currently, they also discuss the solutions and suggestions for the age-old problem. Translations of Tamil Dalit literatures include Bama's novels Karukku, Sangati and short stories that were translated by Lakshmi Holmstrom. Sangati has also been translated into Spanish and French. Imayam's Koveru Kazhuthaigal has been translated into English as The Beast of Burden. Vizhi Pa. Idayavendan's short story has been translated and published by Sahitya Akademi along with other Dalit Tamil translations. The short stories of Imayam, Poomani and Dharman have also been translated into English.

It is surprising to see that only very few books are written and translated by Dalits themselves. Dalit texts, written by one Dalit and translated by another Dalit, are very few in Tamilnadu. For example, the leader of the Dalit Panthers of India, Thol Thirumavalavan's Talisman and Uproot Hindutva, were translated by 
Meena Kandasamy.Sivakami, an activist writer and administrator, has written Pazhayana Kazhitalum, Anandayee and Kurukkuvettu and she is currently engaged in translating them into English. He is also translating Captain S.Kaliyaperumal's Tamilar Unmai Varalaru into English as The True History of Tamils.

Bali Adugal (Scapegoats) is a Tamil Dalit play written and directed by K.A. Gunasekaran. He is well known as an activist, artist, actor, scholar, folk musician, playwright and director. Being a Dalit artist, he has authored many issue-based plays, which were performed in remote villages in Tamil Nadu. He has won many state level honours and awards. His major plays are Sathiya Sodanai, Pavalakkodi or Kudumba Vazhakku, Ariguri, Thodu, Maartram [a play about the eunuchs], Mazhi, Kandan or Valli, Kanavulagavasi, Parayai Pilandhukondu and Thottil Thodangi.

Somewhat surprisingly, Bali Adugal is the only written Dalit play in recent times in India. The play was premiered more than 250 times, both at the regional and the national levels, including one at the National School of Drama's 5th National Theatre Festival, held from 20th March - 8th April 2003. The play was premiered on the 26th of March 2003.

The Thannane Theatre Group headed by K.A.Gunasekaran often premieres the play. Thannane appeared on the theatre scene in 1995. Since then, the group has been creating an awareness of suppression of the oppressed and underprivileged people. It meets the people in every nook and corner of the interior villages of Tamil Nadu and Pondicherry through theatre and folk musical concerts. It is also actively involved in Dalit movements for creating awareness among these people. The group also conducts workshops at the national, state and village levels to help educate the theatre aspirants including by training eunuchs as performers. He also tries to 
construct a theatre for eunuchs to highlight the problems faced by them.

Bali Adugal takes a cue from an inscription, found in a temple of a village in Tamil Nadu, particularly in Kongu Nadu. The inscription is about a human sacrifice that took place in the past. The author with contemporaneity has successfully interpreted this text and highlighted the social oppression that the dalits suffered in the past. The play has textually blended yet another historic dialogue between Ambedkar and Mulk Raj Anand on social oppression which has been extracted from the book Annihilation of Caste written by Ambedkar.

The play depicts the practice of scapegoating and the conflicts between the dominant Brahmins and the downtrodden, the Dalits of the village. In this play, the rich and the powerful Brahmins dominate the poor and the downtrodden of the same village, always ridiculing and suppressing them on all occasions. The play features a scene where a 'rath' (chariot) is carried by dalits and it accidentally breaks. This damage of the rath is attributed to the dalits because a dalit designed it. In order to pacify the village goddess, the Brahmin priests demand a human sacrifice. Hearing the news everyone flees in fear. In the end, a person is identified as the one to be sacrificed but the latter to save his own skin bargains with the priests. He places his wife as the sacrificial lamb and saves himself from being killed. Thus, the play deals with the problem of dalits and how they are victimized by the 'system'. Though the play at the beginning tries to put forward the concept of dalit theatre and to popularise it as a major tool against atrocities against them, in the end, the play turns out to be a strong dalit feminist manifesto.

The songs and music have to be heard and felt during the performance. Or else it would be very difficult to translate the emotive language of this play. Dalit's songs and music vary for death, marriage and war. The introductory and also recurring 
musical song in Bali Adugal is 'Thanthana'. 'Thanthana' is a song of lamentation played often by the dalits to free themselves of the pain they undergo from oppression. It can be compared to the Blues of Afro-American music.

The second song in Bali Adugal begins with (naaluvarna sadhiyela) the description of four Varnas. The music tuned for this song is tragic. The holy thread of the Brahmins and the ropes of the tied Dalits are symbolic. The "threads" and the "ropes" are intertwined with the rhythm of the music and songs. One can find the fusion of the language of music and the language of body in the performance where the Brahmins beat with their holy threads on the tied Dalits. This scene is symbolically enacted to bring out the centuries-old oppression of the Dalits. The symbolic usage of thread, the author said, was designed for the audience

The third song in Bali Adugal is on lahirtham. In Pondicherry children sing this 'song' in schools and on streets. Children jumping across a child who is made to bow down utter this word. Literally speaking the word has no meaning and in the play it is used as a pun to mock at the meaninglessness of the Sanskrit mantras uttered in rituals of the dominant castes.

In their very breath, in the tunes hummed, in their simple mocking songs, in their very use of language, dalits have imbued a rebuffing attitude towards the hegemonic dominance that inheres in the caste hierarchy and it is a Herculean task that befalls the translator to transfer these cultural and linguistic nuances into the targetlanguage.

\section{Human Scapegoats and Bali Adugal}

The practice of human sacrifice was widely prevalent among the ancient Greeks, and in Slavonic ceremonies. In ancient Rome 
Human scapegoats such as Mamurius Returius (Frazer 1993-94) were too common. The King of the Bean in Twelfth Night, the Medieval Bishops of Fools, Abbot of Unreason, or the Lord of Misrule are figures of the same sort in Italy, Spain, and France. A close reading of Frazer's chapters (Frazer 1993-94 LVII and LVIII) on scapegoats in The Golden Bough shows how the servile classes such as slaves, serfs, bondsmen, and generally the poor were used as human scapegoats. Athenians regularly maintained a number of degraded and 'useless' beings for human sacrifice during the period of calamities such as plague, drought or famine in the city. They used to sacrifice two of the outcasts as scapegoats. One of the victims was sacrificed for the men and the other for the women.

The play Bali Adugal takes its cue from this practice of human sacrifice that was widely prevalent in India. In the Indian social context the people chosen as the scapegoats were often people from the backwaters of society and quite often Dalits who refused to abide by the norms of the cast hierarchy. They were chosen as scapegoats with the explicit motive of removing the 'evil' from the body politic though ritualising the whole event and making it look divinely ordained in the eyes of the public. The playwright objectively questions this practice of scapegoating Dalits, at the same time subtly criticising the point of the transference of this oppression on Dalit women.

\section{Texts within Texts in Bali Adugal}

The play opens up multi-layered levels of texts within texts. The text incorporates the conversation between B.R.Ambedkar [BRA] and Mulk Raj Anand [MRA], which took place on an evening in May 1950, on a beach in Cuffe Parade Colaba, Mumbai. The conversation has been extracted from Appendix III of B.R.Ambedkar's Annihilation of Caste. The play apart from taking a cue from an inscription also blends/intertwines the historic conversation throughout the text and turns the text into a dialogue, 
between the dialogues of the play. The play blends different pasts that become histories and reinterprets them with the contemporary problems in mind.

The very opening of the play puts forward the question of meaning and brings forth the politics of the translation of culture and language. The conversation follows:

$\begin{array}{lll}\text { Mulk Raj Anand } \quad: \quad \text { Namaskar, Dr. Ambedkar } \\ \text { Ambedkar } & : \quad \begin{array}{l}\text { I prefer the Buddhist greeting- } \\ \text { Om Mani Padmaye! }\end{array} \\ \text { Mulk Raj Anand } \quad: \quad \begin{array}{l}\text { I agree. How thoughtless we } \\ \text { are! We inherit words without } \\ \text { questioning their meanings! Of, } \\ \text { course, Namaskar means I bow } \\ \text { before you... }\end{array}\end{array}$

Ambedkar : That perpetuates submission! May the lotuses awake is a prayer for enlightenment!

(Ambedkar 1980:130)

This text of the 50's [a historical text] is about the Buddhist text [and practice] of addressing which itself is 2000 years old. These are the opening lines of the play, a conversation about the form of addressing which itself becomes a form of addressing the audience. Further, the conversation also strengthens the meaningmaking process of words by explaining the meaning of the particular word 'idiocy', which means, "going round and round in a circle" [which has not been included in the Tamil translation but is found in the English version of the conversation]. 
Later in a conversation that interludes the play Dr. Ambedkar confesses about his participation in the Constitution Drafting Committee viz. that he was merely a scapegoat, which is the title of the play.

Such inter-textual references reverberate throughout the play. It opens up layers of texts within texts. Basically, the play revolves around a fragment of an inscription which has the dominant people's history or social text inscribed on the stones. The play is a careful intertwining of the historical text - the inscription, expanded and extended into a performance text - the play. In other words, there seems to be a translation of one text into another text or one genre into another. At another level, the play is a blend of dialogues in between the dialogues between B.R.Ambedkar and M.R.Anand. The play opens and ends with the dialogue between two - whereas the dialogues of the characters of the play become a subtext. Again, the dialogue between B.R.Ambedkar and M.R.Anand is a sub- text taken from Appendix III of the main text, Annihilation of Caste. The dialogue as a sub text of a historical text becomes a main text in the play, which spins around the dialogue of the characters. The play is built upon such translation and transformation into an innovative framework of texts and genres.

As noted earlier, the play begins with a conversation between Dr. Ambedkar and Anand. Dr. Ambedkar alerts Anand on the first word he utters 'namashkar', and thereby the politics of language is brought to the forefront.

As for the translator, he is in a unique position with regard to this text i.e., the text of conversation between the two which itself is a translation in Tamil from English (which probably might be a translation from Marathi). One has to note here the point that the play itself is a site of a translated text. 
In this context, it may be in order here to recall the views of Octavia Paz who in his short work on translation claims that all texts, being part of a literary system descended from and related to other systems, are "translations of translations of translations'. He continues:

Every text is unique and, at the same time, it is the translation of another text. No text is entirely original because language itself, in its essence, is already a translation: firstly, of the non-verbal world and secondly, since every sign and every phrase is the translation of another sign and another phrase. However, this argument can be turned around without losing any of its validity: all texts are original because every translation, up to a certain point, is an invention and as such it constitutes a unique text

(quoted in Bassnett 1996)

The whole text itself is an 'inspiration' from a fragment of an inscription. The inscription itself is a round-shaped script ['vattezhuthu' script] which often has to go through a rigorous process of decoding, i.e., a translation to modern Tamil script.

\section{Bali Adugal and the Limits of Hermeneutics}

From another perspective, the play also raises important questions about the limits of interpretation. The first problem one faces is that of recovering the voice of the dalit who was 'sacrificed' according to the inscription. The act of inscription itself is a project of the dominant at the expense of annihilating, effacing the body of the dalit, silencing the voice of the oppressed. To recover the voice of the dalit from a 'document' of the dominant is a project of history, which is basically a hermeneutical project. 
As often happens historical hermeneutics falls into a meta discourse/grand narrative of the nation, the citizen and as a final recourse that of history itself. This is an inevitable risk and pitfall.

It would be appropriate here to recall two attempts at resuscitating fragments. Ranajit Guha in his influential essay "Chandra's Death" reconstructs and reinterprets a fragment of the testimony of judicial discourse for the project of history. In his meticulous analysis of the piece of judicial document, he recovers the voice of the subjugated dalit woman. It is a laudable attempt at recovering the suppressed voices of history from a document of the dominant but there remains the problem of falling into the labyrinth of history for its own sake.

The other attempt by Gyanendra Pandey (Pandey 1994) problematizes the whole project of history itself. Pandey captures the core of the problem, as the "'historians' history, at least the history of the last few centuries, has been predominantly a history of transition". One can translate this as a history of translation. How are we to translate the lived experience of violence, subjugation, of the oppressed, for us, the experience of dalits? Criticizing the historians' history i.e., the academic writing of history on Partition as a "prose of otherness", he contrasts the representation of Partition in the fictional works of Sadat Hasan Manto. Implicitly, he suggests that historical hermeneutics as a project has serious limitations in bringing out the violence and pain that is lived and suffered by the oppressed people and probably art and literature can be the appropriate spheres in bringing out the lived experience of the oppressed, in giving voice in other words to the oppressed who are deprived of their own voices. To recover the voice of the effaced dalit body and its voice is invariably and inevitably a political project of the Arts enmeshed in the present, not that of evoking the past for its own sake. 
In Bali Adugal, this task has been successfully taken up by the artist/activist K. A. Gunasekaran as an artistic reinterpretation of the 'inscribed' event.

\section{Bali Adugal and the Text as an Object of Desire/Love}

The translator's relationship to the text he/she has taken up to translate could be seen as one of amorous love. The translator chooses a particular text basically out of desire. Needless to say, all relationships are enmeshed in a matrix of power. With love, this relationship can be put, in a nutshell, as possessive love: dominant or submissive because one wishes to possess the apple of one's eye.

The problem that arises here for the translator is: can he/she transcend this matrix of the power relationship in the act of translating any particular text?

Could the translator make love to the text he/she has chosen to translate, in a way that is not possessive, i.e., interpretative: fidelity to the original, 'sticking' to the authors 'intentions' or else perfidious to the text, selective in his interpretative maneuver?

Fidelity in love and translation is feminine and perfidy, the subject location of the male. Could one locate a subject location that escapes this binary opposition in the act of translation? Could one in other words perform the act of translation in a way that is not possessive, interpretative or at the least that gets beyond the interpretative maneuver? Could one be flirtive? And could there be a subject location, a figure for the flirtive?

Unexpectedly the text Bali Adugal offers one such figure. Out of the blue, a eunuch emerges from nowhere and laments over the unfairness of the prejudice of sacrificing the dalit woman, her subjection to the subjected dalit male subject location. 
The whole text becomes a limit-text or border text at this juncture in the play. The dalit female who bears the brunt of oppression, who is at the extreme receiving end of the oppressive caste system, subject even to the dalit male, is given voice by an eunuch: a group of people, who are in close proximity to the oppressed, is oppressed by the system and at the same time out of the system. This is what makes the text a border-text that operates at the boundaries, defies classification and creates fissures (Broadhurst, 1999; Humm, 1991). By giving voice to the eunuch, by the eunuch speaking for the dalit female, the text also decidedly refuses to essentialize the dalit identity by moving into a liminal sphere of irreducible difference.

The translator's task is to make love to the text he/she has chosen, as a eunuch would flirt. The figure of the eunuch would be the art and an act of translation. This is not to deny 'seriousness' or 'responsibility' on the part of the translator and interpretation on the whole, but to move beyond interpretation, just as the figure of the eunuch is at the liminal point - both inside the system, oppressed by the system, in close proximity with the oppressed, yet defying classification and out of the system.

The figure of an eunuch and the act of flirting with the text chosen for translation, is to suggest returning to the particular text again and again, a form of rereading which has nothing to do with 'seriousness', not an exercise in search for meanings buried deep within the text but a perverse economy of dispersion, of waste, of frenzy (Barthes 1978). It is an exuberance of the child, which asks for the same story again and again for the sake of the pure pleasure of hearing it. Each recital of the story is a unique exercise in pleasure, in the flush of which the child generates its own images, meanings and hallucinations.

It happened that, this particular translator, in one of his encounters with the text he had chosen to translate, in his 
hallucinations, had this figure of the eunuch emerge from the text itself. And with the simple innocence and exuberance have that story shared here

\section{Challenges}

In the process of translating dalit texts, the following are important challenges that dalit literatures and their translators have to encounter:

\section{Publishing}

Publishing today is a highly competitive arena and the dalits, already a marginalized group, find it difficult to find a space whereby they can get their works published. Several factors work against their interests and getting a foothold in the publishing industry is definitely a Sisyphean task for Dalit writers.

\section{Demands of the Market}

Meeting the demands of the market that is dominated by several factors like the banner of the publishing house and the popularity of a translator, becomes an important problem to be grappled with by Dalit authors. There is a felt need for instituting a publishing industry, which is completely managed by Dalits. The Dalits need to make their strong presence in all the wings of the mass media - from the editorial to the marketing teams. For example, in Canada there is a Press for the First Nations' peoples and women. A similar move would be welcome with the Dalits in India. Dalit publishing networks along with Dalit news agency and Dalit media network must have links with the mainstream counterparts for generating counter-productive programmes. 


\section{Readership}

Readers to a great extent decide the success or failure of a book. As far as Dalit literature is concerned, there is a minority of readers. It is a difficult task to make a dent in the mindset of the general readership but the content and quality of present and future Dalit work will hopefully do it. This is at the same time a hope and a challenge.

\section{Intra-cultural Variations within Dalits at the Regional/National Level}

Even within the Dalit communities there are several layers of differences ranging from their cultural practices to their linguistic preferences. Slang and other forms of language are different among Dalits themselves in the districts of Thanjavur, Ramanathapuram and Madurai of Tamil Nadu. A Dalit from one of these districts has to face some difficulty to understand the slang of a Dalit from another district. The translator thus has to mediate between these extremes and find the appropriate mode of expression while translating literatures written by Dalits of different districts.

\section{Translation / Power Relations}

The practice of translation carries within itself the seeds of power relations. Earlier, the emphasis in the world of translation was on the quality of translation but now there is a perceptible shift from the author to the translator. Who translates a particular work makes all the difference. The best example is that of the English versions of Russian classics translated by Constance Garnett. There is a politics of the text, of the author, of the translator and of the publisher. Writers and Dalits wish to see their works published in the mainstream publishing houses and in foreign languages and they welcome them. 
* I owe a debt of gratitude to Mr.Valarmathi, a free-lancing scholar, poet, journalist, documentary director, translator, playwright, performer, and a critic, for his critical acumen and insights but for which this piece wouldn't have been in the form it is.

\section{REFERENCES}

Ambedkar, B.R. (1980) The Annihilation of Caste Delhi: Arnold. Publishers.

Barthes, Roland. (1978) A Lover's Discourse: Fragments. New York: Hill and Wang.

Bassnett, Susan. (1991) Translation Studies London: Routledge.

Broadhurst, Susan (1999) Liminal Acts: A Critical Overview of Contemporary Performance and Theory. London: Cassell.

Coltelli, Laura (1990) Winged Words. Nebraska: U of Nebraska Press.

Frazer, Sir James. (1993-94) The Golden Bough: A Study in magic and religion.Hertfordshire: Wordsworth.

Guha, Ranajit. (1987) Chandra's Death in David Arnold and David Hardiman (Ed.) Subaltern Studies Vol.V. New Delhi: OUP.

Gunasekaran, K.A. (1999) Dalit Kalai, Kalacharam, Chennai: Raagas.

Gunasekaran, K.A. (2003a) Bali Adugal. Chennai: Kavya. 
Gunasekaran, K.A. (2003b) Serippuraviyal Chennai: Thannane.

Humm, Maggie (1991) Border Traffic: Strategies of Contemporary Women Writers. Manchester: Manchester University Press.

Pandey, Gyanendra (1994) The Prose of Otherness in David Arnold and David Hardiman. (Ed.) Subaltern Studies Vol. VIII. New Delhi: OUP.

Simon, Sherry (1996) Gender in Translation: Cultural Identity and the Politics of Translation. London: Routledge.

Venuti, Lawrence (2002) The Translation Studies Reader New York: Routledge. 
